\title{
DISTRIBUTION OF COBALT, VANADIUM AND CHROMIUM BETWEEN COEXISTING BIOTITE AND GARNET IN GRANULITE FACIES ROCK SAMPLES
}

\author{
Kalevi Korsman
}

\begin{abstract}
Korsman, Kalevi 1975: Distribution of cobalt, vanadinium and chromium between coexisting biotite and garnet in granulite facies rock samples. Bull. Geol Soc. Finland 47, 13-17.
\end{abstract}

\begin{abstract}
The distribution coefficients of cobalt, vanadium and chromium were determined in biotite-garnet pairs of granulite facies rock samples. The sample areas are Lapland, West Uusimaa and Sulkava. The distribution of cobalt between biotite and garnet is linear, $\mathrm{K}_{\mathrm{D}}$ being 1.7. The distribution points of vanadium fall close to a straight line, the slope of which is 9.8 . The chromium distribution points are scattered. A relationship, however, is apparent between the chromium distribution coefficient and the atomic ratio $\mathrm{Mg} / \mathrm{Fe}+\mathrm{Mg}+$ $\mathrm{Mn}$ of garnet. The distribution coefficient decreases with an increase in the $\mathrm{Mg} / \mathrm{Mg}+\mathrm{Fe}+\mathrm{Mn}$ of garnet.
\end{abstract}

Kalevi Korsman, Geological Survey of Finland, SF-02150 Espoo 15, Finland.

\section{Introduction}

The distribution coefficients of trace elements between coexisting garnet, biotite and hornblende have been determined, e.g. by Kretz (1959). The thermodynamics of the distribution of trace elements between coexisting phases has been discussed by McIntire (1963). When considering the distribution of trace elements between coexisting minerals, the fundamental principle is an application of the Berthelot-Nernst distribution law: $\frac{x_{1}}{x_{2}}=K_{D}$. In the equation $x_{1}$ and $x_{2}$ are the concentrations of the trace element in mineral phases 1 and 2 . If the distribution of the trace element is ideal and if two phases coexist at equilibrium, the distribution coefficient is a function of temperature and pressure alone. However, variations in the chemical compositions in the coexisting phases may have an influence on the distribution coefficient. If this is the case, the distribution coefficient may also depend on a third mineral phase.

Garnet-cordierite gneisses are very common rocks in the Precambrian of Finland. Some garnet-cordierite gneisses belong to the granulite facies, like the cordierite granulites of Lapland (Eskola 1952) and the lutogenites of West Uusimaa (WUC) (Parras 1958). This paper presents the distribution of cobalt, vanadium and chromium between coexisting biotite and garnet in garnet-cordierite gneisses of the granulite facies. 


\section{Samples}

The samples of this study were taken from the granulite area of Lapland, from the charnockite area of the WUC and from the garnet-cordierite area of Sulkava.

The samples from Lapland are cordierite granulites. According to Eskola (1963), cordierite is not one of the granulite facies minerals. The cordierite granulites of Lapland may, however, be considered as members of a subfacies of the granulite facies. The samples contain the following mineral assemblage: quartz-potash feldspar-biotite-garnet-cordierite-sillimanite \pm placioclase.

According to Parras (1958), all the rocks of the WUC originated by ultrametamorphism, mineral assemblages attaining their equilibrium under conditions of the granulite facies. The Ca-content of the metamorphosed rock was a main factor controlling the crystallization of hypersthene, instead of garnet and cordierite. The mineral assemblages of the WUC samples are: quartz-potash feldspar-biotite-garnet-cordierite-sillimanite \pm placioclase and quartz-placioclase-biotite-garnet (sample no. 17).

The rocks of the Sulkava sample area in eastern Finland (Korsman and Lehijärvi 1973) are predominantly garnet-cordierite gneisses migmatized by potash granite. In addition, hypersthene gneisses and metamorphosed hypersthene-bearing granodiorites and quartz diorites occur in the area. The increasing $\mathrm{Ca}$-content of the rock has also favoured the crystallization of hypersthene in the Sulkava area. The samples contain the mineral assemblages: quartz-potash feldspar-biotite-garnet-cordierite-sillimanite \pm placioclase and quartz - placioclase - biotite - garnet - hypersthene (samples nos. 61 and 66 a). According to the mineral assemblages, the garnet-cordierite gneisses of Sulkava crystallized under the conditions of the biotite-cordierite-almandine-granulite subfacies.

Bictites and garnets were separated from crushed and sieved material by heavy liquids, isodynamic separator and hand picking.

\section{Results}

Table 1 presents the $\mathrm{Co}, \mathrm{Cr}$ and $\mathrm{V}$ contents of the minerals and the distribution coefficients. The distribution points are plotted in Figs. $1-3$ on logarithmic scales. If the distribution follows the Berthelot-Nernst distribution law, the slope of the distribution line is $45^{\circ}$ on such a plot.

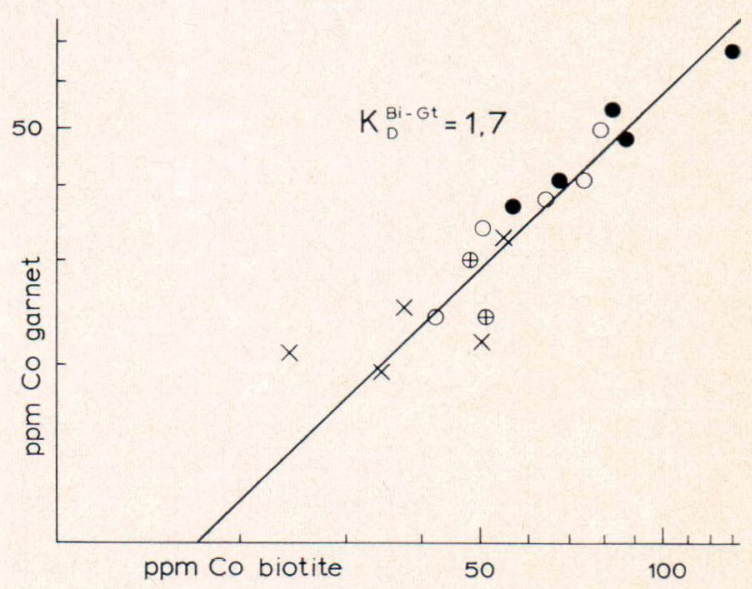

Fig. 1. Distribution of cobalt between coexisting biotite and garnet. Scale is logarithmic. Symbols are: open circles-Sulkava samples, open circles with crosses-hypersthene-bearing Sulkava samples, solid circles-WUC samples, inclined crosses-cordierite granulites of Lapland.

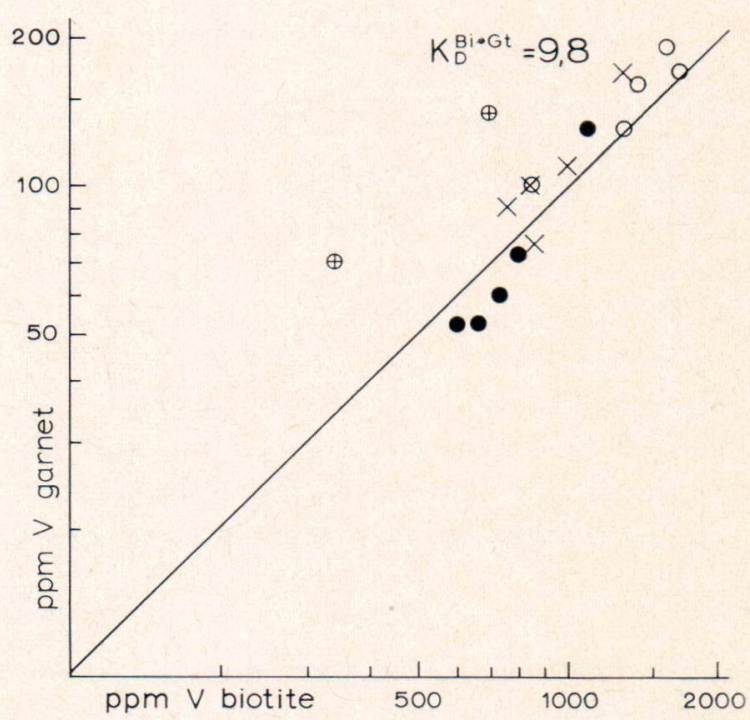

Fig. 2. Distribution of vanadium between coexisting biotite and garnet. Scale is logarithmic. Symbols are as in Fig. 1. 
TABLE 1

Emission spectrometric determinations of cobalt, vanadium and chromium (in parts per million) in biotite and garnet and distribution coefficients

\begin{tabular}{|c|c|c|c|c|c|c|c|}
\hline Sample No. & & V & $\mathrm{Cr}$ & Co & $K_{D}(V)$ & $\mathrm{K}_{\mathrm{D}}(\mathrm{Cr})$ & $\mathrm{K}_{\mathrm{D}}(\mathrm{Co})$ \\
\hline \multicolumn{8}{|l|}{ Lapland } \\
\hline \multirow{2}{*}{$01 \mathrm{a} / \mathrm{KK} / 70^{* *}$} & biotite & 1000 & 630 & 50 & 9.1 & 2.0 & 2.3 \\
\hline & $\begin{array}{l}\text { garnet } \\
\text { biotite }\end{array}$ & $\begin{array}{l}110 \\
760\end{array}$ & $\begin{array}{l}320 \\
580\end{array}$ & $\begin{array}{l}22 \\
24\end{array}$ & & & \\
\hline $01 \mathrm{~b} / \mathrm{KK} / 70^{* *}$ & garnet & 90 & 330 & $\begin{array}{l}24 \\
21\end{array}$ & 8.4 & 1.8 & 1.1 \\
\hline \multirow{2}{*}{$01 \mathrm{~d} / \mathrm{KK} / 70^{* *}$} & biotite & 840 & 510 & 54 & 8.4 & 1.7 & 1.6 \\
\hline & garnet & 100 & 300 & 33 & & & \\
\hline \multirow[t]{2}{*}{$01 \mathrm{e} / \mathrm{KK} / 70^{* *}$} & biotite & 860 & 650 & 37 & 11.3 & 2.5 & 1.5 \\
\hline & garnet & 76 & 260 & 25 & & & \\
\hline \multirow[t]{2}{*}{$02 \mathrm{~b} / \mathrm{KK} / 70^{* *}$} & biotite & 1300 & 920 & 34 & 7.6 & 2.7 & 1.8 \\
\hline & garnet & 170 & 340 & 19 & & & \\
\hline \multirow[t]{2}{*}{$01 / \mathrm{KK} / 69^{* *}$} & biotite & 1100 & 1100 & 130 & 8.5 & 3.7 & 1.9 \\
\hline & garnet & 130 & 300 & 68 & & & \\
\hline \multirow[t]{2}{*}{$02 / \mathrm{KK} / 69^{* *}$} & biotite & 730 & 800 & 86 & 12.2 & 4.2 & 1.8 \\
\hline & garnet & 60 & 190 & 48 & & & \\
\hline \multirow[t]{2}{*}{$017 / \mathrm{KK} / 69^{* *}$} & biotite & 600 & 560 & 56 & 11.5 & 3.3 & 1.5 \\
\hline & garnet & 52 & 170 & 37 & & & \\
\hline \multirow[t]{2}{*}{$018 / \mathrm{KK} / 69^{* *}$} & biotite & 800 & 820 & 82 & 11.1 & 4.6 & 1.5 \\
\hline & garnet & 72 & 180 & 54 & & & \\
\hline \multirow[t]{2}{*}{$020 / \mathrm{KK} / 69^{* *}$} & biotite & 660 & 700 & 67 & 12.7 & 5.0 & 1.6 \\
\hline & \multicolumn{6}{|c|}{ Sulkava } & \\
\hline \multirow[t]{2}{*}{$21 / \mathrm{IL} / 61^{*}$} & biotite & 1700 & 1200 & 42 & 10.0 & 3.6 & 1.8 \\
\hline & garnet & 170 & 330 & 24 & & & \\
\hline \multirow[t]{2}{*}{$307 / \mathrm{KV} / 63^{*}$} & biotite & 1400 & 790 & 79 & 8.8 & 3.0 & 1.6 \\
\hline & garnet & 160 & 260 & 50 & & & \\
\hline \multirow[t]{2}{*}{$20 \mathrm{a} / \mathrm{KK} / 67^{*}$} & biotite & 1600 & 870 & 74 & 8.4 & 3.8 & 1.8 \\
\hline & garnet & 190 & 230 & 41 & & & \\
\hline \multirow{2}{*}{$61 / \mathrm{KK} / 69^{* *}$} & biotite & 700 & 230 & 51 & $(5.0)$ & 1.6 & 2.1 \\
\hline & garnet & 140 & 140 & 24 & & & \\
\hline \multirow{2}{*}{$64 / \mathrm{KK} / 69^{* *}$} & biotite & 1300 & 1200 & 51 & 10.0 & 5.5 & 1.5 \\
\hline & garnet & 130 & 220 & 34 & & & \\
\hline \multirow[t]{2}{*}{$65 / \mathrm{KK} / 69^{* *}$} & biotite & 850 & 780 & 64 & 8.5 & 4.3 & 1.7 \\
\hline & garnet & 100 & 180 & 38 & & & \\
\hline \multirow[t]{2}{*}{$66 \mathrm{a} / \mathrm{KK} / 69^{* *}$} & biotite & 340 & 100 & 48 & $(4.9)$ & 0.9 & 1.6 \\
\hline & garnet & 70 & 110 & 30 & & & \\
\hline \multicolumn{2}{|c|}{ arithmetic mean } & & & & 9.8 & & 1.7 \\
\hline
\end{tabular}

* Anal. Ringa Danielsson.

** Anal. A. Löfgren.

In general the distribution points of cobalt fall close to a straight line, the mean value of the distribution coefficient being 1.7. The distribution coefficients of samples $01 \mathrm{a}, 01 \mathrm{~b}$ and 61 deviate markedly from this mean value. The causes of the scattering may be as follows: the mineral fractions contained impurities, the samples were unhomogenous, equilibrium was not attained between biotite and garnet or the deviating samples crystallized at pressures and temperatures different from those of the other samples.
The distribution of vanadium between biotite and garnet is also regular. The mean value of $K_{D}$ is 9.8. The distribution coefficients of the hypersthene-bearing Sulkava samples are markedly lower than those of the other Sulkava samples. If the distribution of vanadium between biotite and garnet in the mineral assemblage biotite-garnet is different from that in garnetbiotite-hypersthene, changes in the chemical compositions of the mineral pairs must indicate a change in the distribution coefficients.

The distribution points of chrome are scat- 
tered. The distribution coefficients of the Sulkava hypersthene-bearing samples are much lower than the $K_{D}$ values of the other Sulkava samples. This may be because the biotites of the hypersthene-bearing samples are much lower in $\mathrm{Cr}$ than are the biotites of the other Sulkava samples.

The distribution coefficients of the Lapland

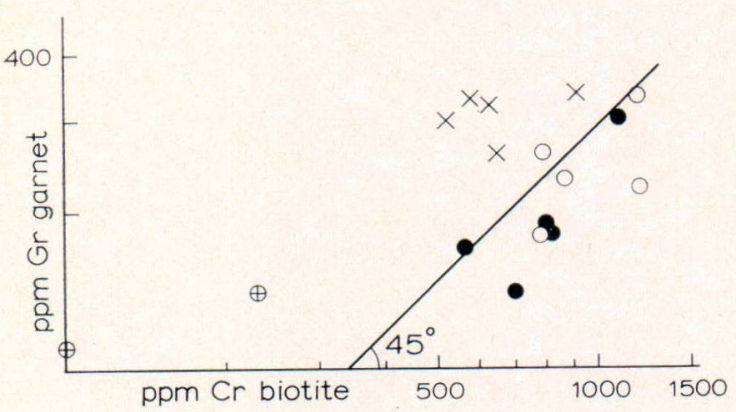

Fig. 3. Distribution of chromium between coexisting biotite and garnet. Scale is logarithmic. Symbols are as in Fig. 1.

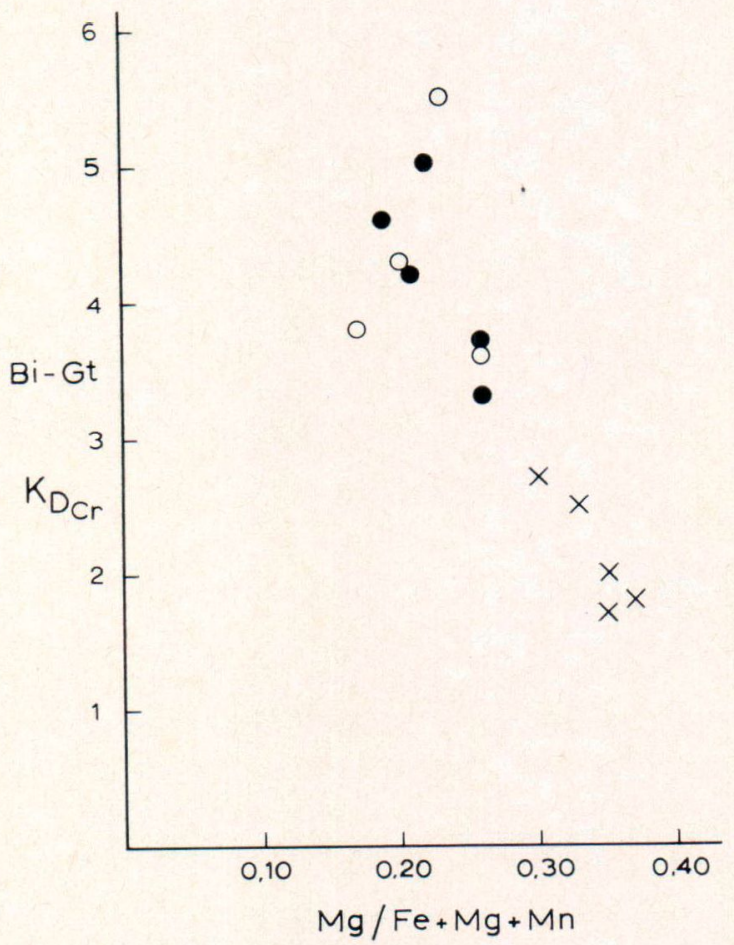

Fig. 4. Influence of the magnesium atomic ratio on the distribution coefficient of chromium in biotite-garnet pairs. Symbols are as in Fig. 1. samples deviate considerably from those of the other samples. Table 2 lists the results of $\mathrm{Fe}$ - and $\mathrm{Mg}$-microprobe determinations of the garnets. From Fig. 4 it is seen that the chrome distribution coefficients decrease with the increasing atomic ratio $\mathrm{Mg} / \mathrm{Fe}+\mathrm{Mg}+\mathrm{Mn}$ of garnet.

The regular distributions of cobalt and vanadium indicate that chemical equilibrium was attained in the biotite-garnet pairs and that the distributions follow the Berthelot-Nernst distribution law. It may be possible, however, that changes in the chemical compositions of the mineral pairs influence the vanadium distribution coefficient. This is indicated by the low $\mathrm{K}_{\mathrm{D}}$ values of the hypersthene-bearing Sulkava samples. A correlation exists between the chromium distribution coefficients and the atomic ratio $\mathrm{Mg} /$ $\mathrm{Mg}+\mathrm{Fe}+\mathrm{Mn}$ of garnet. This is also in agreement with the supposition that equilibrium was attained between garnet and biotite. It is not known how the distribution coefficients depend on crystallization temperature and pressure, nor what crystallization temperature is implied by the cobalt distribution coefficient 1.7 and the vanadium distribution coefficient 9.8 .

\section{TABLE 2}

$\mathrm{FeO}-, \mathrm{MgO}-$ and $\mathrm{MnO}$-microprobe determinations of garnets. Anal. B. Saltikoff

\begin{tabular}{|c|c|c|c|c|}
\hline \multirow{2}{*}{ Sample No. } & \multirow{2}{*}{$\begin{array}{c}\text { Fetot } \\
\text { as } \mathrm{FeO}\end{array}$} & \multirow{2}{*}{$\mathrm{MgO}$} & \multirow{2}{*}{$\mathrm{MnO}$} & $\mathrm{Mg}$ \\
\hline & & & & $\mathrm{Fe}+\mathrm{Mg}+\mathrm{Mn}$ \\
\hline \multicolumn{5}{|l|}{ Lappi } \\
\hline $01 \mathrm{a} / \mathrm{KK} / 70 \ldots$ & 31.5 & 9.7 & 0.5 & 0.35 \\
\hline $01 \mathrm{~b} / \mathrm{KK} / 70 \ldots$ & 30.6 & 10.3 & 0.5 & 0.37 \\
\hline $01 \mathrm{~d} / \mathrm{KK} / 70 \ldots$ & 32.2 & 9.9 & 0.5 & 0.35 \\
\hline $01 \mathrm{e} / \mathrm{KK} / 70 \ldots$ & 31.3 & 8.8 & 0.5 & 0.33 \\
\hline $02 \mathrm{~b} / \mathrm{KK} / 70 \ldots$ & 32.6 & 8.0 & 0.5 & 0.30 \\
\hline \multicolumn{5}{|l|}{ WUC } \\
\hline $01 / \mathrm{KK} / 69 \ldots$ & 32.5 & 6.4 & 0.9 & 0.26 \\
\hline $02 / \mathrm{KK} / 69 \ldots$ & 32.8 & 5.1 & 0.8 & 0.21 \\
\hline $017 / \mathrm{KK} / 69 \ldots$ & 33.7 & 6.9 & 0.6 & 0.26 \\
\hline $018 / \mathrm{KK} / 69 \ldots$ & 33.3 & 4.6 & 0.7 & 0.19 \\
\hline $020 / \mathrm{KK} / 69 \ldots$ & 31.4 & 5.1 & 0.7 & 0.22 \\
\hline \multicolumn{5}{|l|}{ Sulkava } \\
\hline $21 / \mathrm{IL} / 61 \ldots$ & 32.8 & 6.4 & 0.6 & 0.26 \\
\hline $20 \mathrm{a} / \mathrm{KK} / 67 \ldots$ & 34.6 & 4.0 & 0.5 & 0.17 \\
\hline $64 / K K / 69 \ldots$ & 31.8 & 5.5 & 0.5 & 0.23 \\
\hline $65 / \mathrm{KK} / 69 \ldots$ & 35.2 & 4.9 & 0.5 & 0.20 \\
\hline
\end{tabular}


Acknowledgements - I wish to thank Professor K. J. Neuvonen and Professor A. Simonen for critically reading the manuscript, Dr. K. Meriläinen for information about the granulites of Lapland, Miss Ringa Daniel- son (M.Sc.), Mr. A. Löfgren (M.Sc.) and Mr. B. Saltikoff (M.Sc.) for analytical work, Mrs. Anni Vuori for drawing the figures and Mrs. Gillian Häkli for correcting the English.

\section{REFERENCES}

Eskola, P. (1952) On the granulites of Lapland. Am. J. Sci. Bowen. 1: 133-171

Eskola, P. (1963) The Precambrian of Finland. Pp. $144-263$ in The Precambrian I, ed. by K. Rankama.

Korsman, K. and LeHJü̈rvi, M. (1973) Kallioperäkartan selitykset, 3144 Sulkava. Summary: Precambrian rocks of the Sulkava map-sheet area. Suomen geologinen kartta, 1: $100000.24 \mathrm{p}$.

Kretz, R. (1959) Chemical study of garnet, biotite and hornblende from gneisses of southwestern Quebec, with emphasis on distribution of elements in coexisting minerals. J. Geol. 67: 371-402.

McIntrRe, W. L. (1963) Trace element partition coefficients, a review of theory and applications to geology. Geochim. et Cosmochim. Acta 27: 1209-1264.

Parras, K. (1958) On the charnockites in the light of a highly metamorphic rock complex in southwestern Finland. Bull. Comm. Géol. Finlande 181.

Manuscript received, May 30, 1974. 